\title{
ELUCIDATING THE ROLE OF ASSERTIVENESS ON SOCIAL PERFORMANCE OF WOMEN ENTREPRENEURS IN NIGERIA
}

\author{
Mercy Agumadu ${ }^{1^{*}}$, Chinonye L. Moses ${ }^{2}$ and Anthonia A. Adeniji ${ }^{3}$ \\ ${ }^{1}$ Ms. Covenant University, NIGERIA, mercy.agumadu@covenantuniversity.edu.ng \\ ${ }^{2}$ Prof, Covenant University, NIGERIA, chinonye.moses@covenantuniversity.edu.ng \\ ${ }^{3}$ Dr. Covenant University, NIGERIA, anthonia.adeniji@covenantuniversity.edu.ng \\ ${ }^{*}$ Corresponding Author
}

\begin{abstract}
In today's business world, social performance is being considered to be in two major dimensions, social responsibility and social responsiveness and both are important aspects that entrepreneurs need to engage in judiciously. Entrepreneurial traits have been considered an important aspect of entrepreneurship that needs to be looked into considerably because of its significance to the business performance and survival of SMEs. Assertiveness, being an important trait of women entrepreneurs has received research attention lately. Therefore, the paper examined the role of assertiveness of women entrepreneurs on social performance of SMEs in Nigeria. The paper adopted exploratory research method in which the researcher made use of the survey, descriptive and structural design. Five hundred and twenty (520) copies of questionnaire were administered among the selected Nigerian women in SMEs with an 89.2 percent response rate. The target population were women entrepreneurs in Nigeria and the high response rate was achieved due to constant visit to their general monthly meetings. The result was analysed using the structural equation model - Partial Least Squares (SEM-PLS). The path co-efficient revealed that three of the items used to measure assertiveness has a positive and significant influence on social performance. Moreover, one of the items of measurement for assertiveness has a negative but significant influence on social performance. The study concluded that there is a significant relationship between assertiveness and social performance, and recommends that women entrepreneur should allocate funds annually to engage in social performance and government should also provide supporting policies for the entrepreneurs especially women in Nigeria.
\end{abstract}

Keyword: Assertiveness, Social performance, Women, SMEs, Nigeria

\section{INTRODUCTION}

Entrepreneurship is a process of creating and innovating new businesses and development of new business methods and vision by an entrepreneur to produce incremental value and wealth and there by contributing to economic growth (Moses, Olokundun, Akinbode \& Agboola, 2016). Entrepreneurship is often showcased in small and medium scale enterprises (SME). The entrepreneurship that is part of SMEs is very relevant, giving adequate opportunities for the use of local raw materials for vertical and horizontal linkages of business (Abdullahi, Abubakar, Aliyu, Umar, Umar, Sabiu, ... \& Abubakar (2015). Ehigoren \& Eneh (2019) also identified that the entrepreneurs' commitment to social performance and responsibility can lead to attracting customers and can provide a good business strategy. Furthermore, the primary aim of every business is value addition to the customers both as goods, services, or social performance (Aderoba, Babajide \& Adesina, 2015). Studies such as Eib and Siegart (2019) identified the need for an entrepreneur to 
possess the ability to be assertive.

Assertiveness is the ability to be able to stand up for one's or other people's rights calmly and positively, without being aggressive, especially in relation with customers (Anlesinya, Adepoju \& Richter, 2019). Being assertive requires a level of interaction with the environment, customers, and employees using persuasive ability and interpersonal skills, which is a trait that is prominent in women entrepreneurs (Ojinta \& Halkias, 2019). Northouse (2016) supports this view, suggesting that women are becoming more and more assertive in their day-to-day entrepreneurial activities. Studies of Udemba, (2020) and Nwosu, (2019) have considered assertiveness and an important skill that entrepreneurs needs to possess for maximum performance while the studies of Bikefe, Zubairu, Araga, Maitala, Ediuku and Anyebe, (2020) have also asserted that there are business opportunities attached to social performance. Nevertheless, considering the relationship between assertiveness and social performance, one dimension of major relevance that has not been well established in literature is the study of the impact of women entrepreneurs' assertiveness on social performance in the Nigerian context. The objective of the study is to assess the influence of assertiveness of women entrepreneurs on the social performance of an SME.

The hypothesis is written as:

$H_{0}$ : Assertiveness of women entrepreneurs does not significantly influence the social performance of SMEs.

\section{METHODOLOGY}

The paper adopts a survey and descriptive research design for the study. Four indigenous Small and Medium-Scale Enterprises considered for this study are registered members or affiliated with Association of Micro Enterprise (AMEN), NASME Women Group (NASME), National Association of Small Scale Industrialists (NASSI) and NECA's Network of Entrepreneurial Women (NNEW). Four hundred and sixty-four copies of questionnaire were successfully recovered out of the five hundred and twenty copies that were distributed, leading to $89.2 \%$ level of response which was achieved by constant and frequent visitations to the associations' general meetings. Crobach's Alpha was used to validate the research instrument with a result of 0.88 . To show the predictive path coefficients among the variables, the study adopted a variancebased model, specifically Structural equation Modelling (SEM)-Partial Least Square (PLS).

\section{ANALYSIS}

The descriptive statistics and inferential statistics of the two variables assertiveness of women entrepreneurs and social performance are presented in this section.

Table 1: Descriptive Statistics of Assertiveness and Social Performance

\begin{tabular}{|l|c|c|c|c|c|c|c|c|c|}
\hline & SA & A & D & SD & AMEN & NASME & NASSI & NNEW & $\begin{array}{l}\text { AVE } \\
\text { MEAN }\end{array}$ \\
\hline Assertiveness (As) & $\begin{array}{c}\text { Fre } \\
(\%)\end{array}$ & $\begin{array}{c}\text { Fre } \\
(\%)\end{array}$ & $\begin{array}{c}\text { Fre } \\
(\%)\end{array}$ & $\begin{array}{c}\text { Fre } \\
(\%)\end{array}$ & Mean & Mean & Mean & Mean & \\
\hline confident about quality & $\begin{array}{c}183 \\
(39.4)\end{array}$ & $\begin{array}{c}275 \\
(59.3)\end{array}$ & $\begin{array}{c}3 \\
(0.6)\end{array}$ & $\begin{array}{c}3 \\
(0.6)\end{array}$ & 3.190 & 3.408 & 3.407 & 3.513 & $\mathbf{3 . 3 7}$ \\
\hline $\begin{array}{l}\text { focused on tasks in spite } \\
\text { of distractions }\end{array}$ & $\begin{array}{c}159 \\
(34.3)\end{array}$ & $\begin{array}{c}270 \\
(58.2)\end{array}$ & $\begin{array}{c}30 \\
(6.5)\end{array}$ & $\begin{array}{c}5 \\
(1.1)\end{array}$ & 3.142 & 3.266 & 3.252 & 3.373 & $\mathbf{3 . 2 5}$ \\
\hline solve immediate problems & $\begin{array}{c}145 \\
(31.3)\end{array}$ & $\begin{array}{c}307 \\
(66.2)\end{array}$ & $\begin{array}{c}9 \\
(1.9)\end{array}$ & $\begin{array}{c}3 \\
(0.6)\end{array}$ & 3.111 & 3.241 & 3.271 & 3.513 & $\mathbf{3 . 2 8}$ \\
\hline $\begin{array}{l}\text { know exactly what our } \\
\text { customers want }\end{array}$ & $\begin{array}{c}152 \\
(32.8\end{array}$ & $\begin{array}{c}290 \\
(62.5)\end{array}$ & $\begin{array}{c}19 \\
(4.1)\end{array}$ & $\begin{array}{c}3 \\
(0.6)\end{array}$ & 3.111 & 3.316 & 3.281 & 3.400 & $\mathbf{3 . 2 7}$ \\
\hline Social Performance (SP) \\
$\begin{array}{l}\text { make the best use of } \\
\text { available time/resources }\end{array}$ & $\begin{array}{c}166 \\
(35.8)\end{array}$ & $\begin{array}{c}288 \\
(62.1)\end{array}$ & $\begin{array}{c}7 \\
(1.5)\end{array}$ & $\begin{array}{c}3 \\
(0.6)\end{array}$ & 3.134 & 3.325 & 3.310 & 3.565 & $\mathbf{3 . 3 2}$ \\
\hline $\begin{array}{l}130 \\
\text { effectively achieve my } \\
\text { stated social goal }\end{array}$ & $\begin{array}{c}288 \\
(62.0)\end{array}$ & $\begin{array}{c}44 \\
(9.5)\end{array}$ & $\begin{array}{c}2 \\
(0.4)\end{array}$ & 3.158 & 3.166 & 3.126 & 3.252 & $\mathbf{3 . 1 7}$ \\
\hline $\begin{array}{l}\text { yearly allocate somen } \\
\text { funds for meeting societal } \\
\text { expectation }\end{array}$ & $\begin{array}{c}78 \\
(16.8)\end{array}$ & $\begin{array}{c}271 \\
(58.4)\end{array}$ & $\begin{array}{c}93 \\
(20.0)\end{array}$ & $\begin{array}{c}22 \\
(4.7)\end{array}$ & 3.166 & 2.683 & 2.679 & 2.921 & $\mathbf{2 . 8 7}$ \\
\hline
\end{tabular}




\begin{tabular}{|l|c|c|c|c|c|c|l|l|l|}
\hline $\begin{array}{l}\text { I constantly create } \\
\text { awareness about social } \\
\text { responsibility }\end{array}$ & $\begin{array}{c}104 \\
(22.4)\end{array}$ & $\begin{array}{c}295 \\
(63.6)\end{array}$ & $\begin{array}{c}59 \\
(12.7)\end{array}$ & $\begin{array}{c}6 \\
(1.3)\end{array}$ & 3.166 & 3.083 & 3.019 & 3.000 & $\mathbf{3 . 0 7}$ \\
\hline
\end{tabular}

Table 1 shows the descriptive statistics of assertiveness of women entrepreneurs and social performance. Each of the variable was measured with four (4) items as indicated in the table. It is imperative to note that four (4) point Likert's scale that ranges from strongly agree (4) agree (3), disagree (2) and strongly disagree (1). Most of the respondents, which accounted for $58.2 \%$, agreed that women entrepreneurs stay focused on tasks in spite of distractions and interruptions while 59.3\% agreed that women entrepreneurs are confident about the quality of their product/service. $62.5 \%$ of the respondents agreed that women entrepreneurs know exactly what their customers want.

Table 1 also depicts the descriptive statistics for social performance. Most of the respondents, which accounted for $62.1 \%$ agreed that women entrepreneurs often make the best use of available time/resources. It was also discovered that, $62.1 \%$ agreed that women entrepreneurs effectively achieve their stated social goal in creating values for their customers. However, most of the respondents, which accounted for $58.4 \%$, agreed that women entrepreneurs' firms yearly allocate some funds for meeting societal expectation and $86 \%$ of the respondents agreed that women entrepreneurs constantly create awareness about their business social performance engagement. Based on the mean scores, it was discovered that respondents indicated that being confident about the quality of their goods and services serves as the highest measure for assertiveness, which had the highest mean score of 3.37. In addition, as relating to the social performance of SMEs, with a mean score of 3.32 , respondents indicated that women entrepreneurs always make the best use of the available time and resources available to them.

\section{$\mathrm{H}_{0}$ : Assertiveness of women entrepreneurs does not significantly influence social performance of SMEs.}

There are two main variables in the formulated hypothesis, namely assertiveness of women entrepreneurs and social performance. Some of the indicators for the determinant of the level of relationships and the resultant effect in smart PLS are R-Square i.e. the coefficient of determination, structural path co-efficient (B value), T-statistic value, the degree of goodness of model fit among other (Wong, 2013). Also PLS Algorithm Model is a structure of regressions in terms of weight vectors as depicted in Figure 1. PLS Bootstrapping Model with $\beta$ and P values and PLS Bootstrapping Model with $\beta$ and T values are presented in Figures 2, and 3 respectively shows the statistical significance of various PLS-SEM results such path coefficients, R-square, validity and reliability of the instruments among others (Henseler, Ringle \& Sinkovics, 2009).

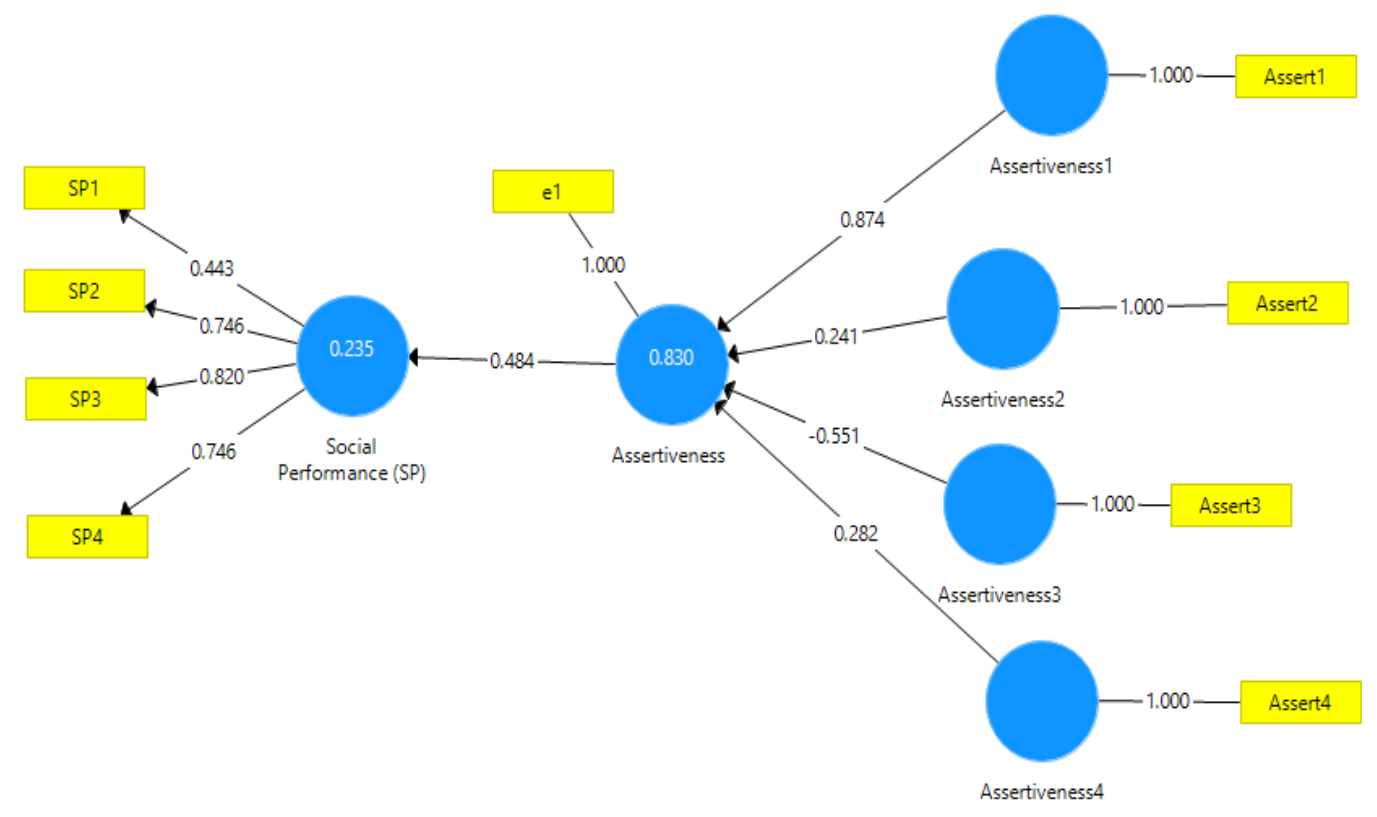

Figure 1: PLS Algorithm Model 
Note: Asset1=Confident in the quality of products/services, Asset2=Focusing on task, Asset3=Solving problems immediately, Asset4=Customers want identification. SP1=Using best available resources, $S P 2=$ Creating value via social goals, $S P 3=A l l o c a t i o n$ of funds for societal expectations, SP4= Social performance engagement awareness.

Figure 1 shows the PLS algorithm model of assertiveness of women entrepreneurs and social performance. The path shows the level of relationship between the two variables. $R$ square $\left(R^{2}\right)$ values, which is categorised into substantial, moderate and weak with the following values $\geq 0.75, \geq 0.50$ and $\geq 0.25$ respectively. Figure 1 shows that the $R^{2}=0.830$ for assertiveness of women entrepreneurs and 0.235 for social performance. This implies that all the factor-loading items of social performance substantially explain $83.0 \%$ of the variance in assertiveness of women entrepreneurs. In a related development, the figure also depicts that assertiveness of women entrepreneurs also explains $23.5 \%$ of the variability of social performance. This implies that the items of assertiveness of women entrepreneurs weakly but significantly explain $23.5 \%$ of the variance in social performance.

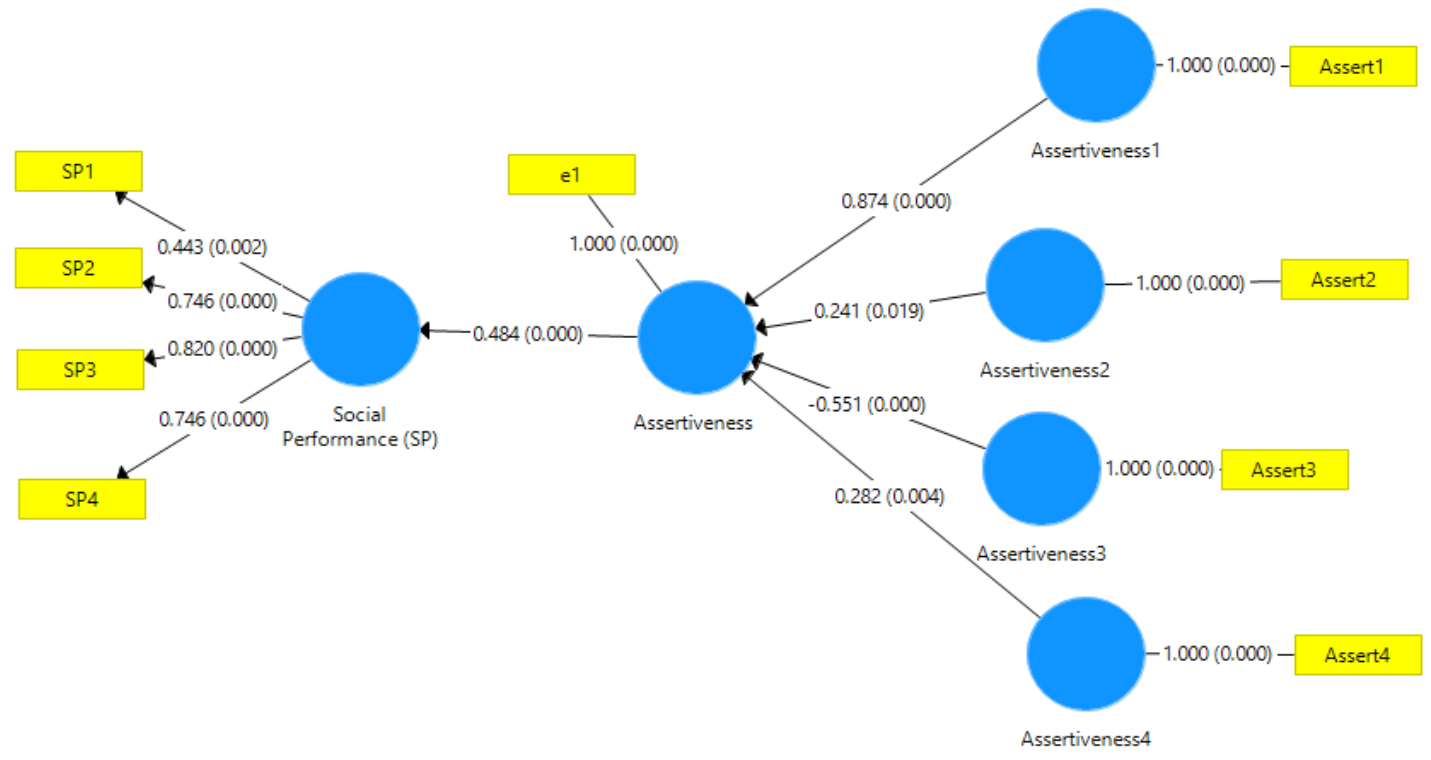

Figure 2: PLS Bootstrapping Model with $\beta$ and P Values

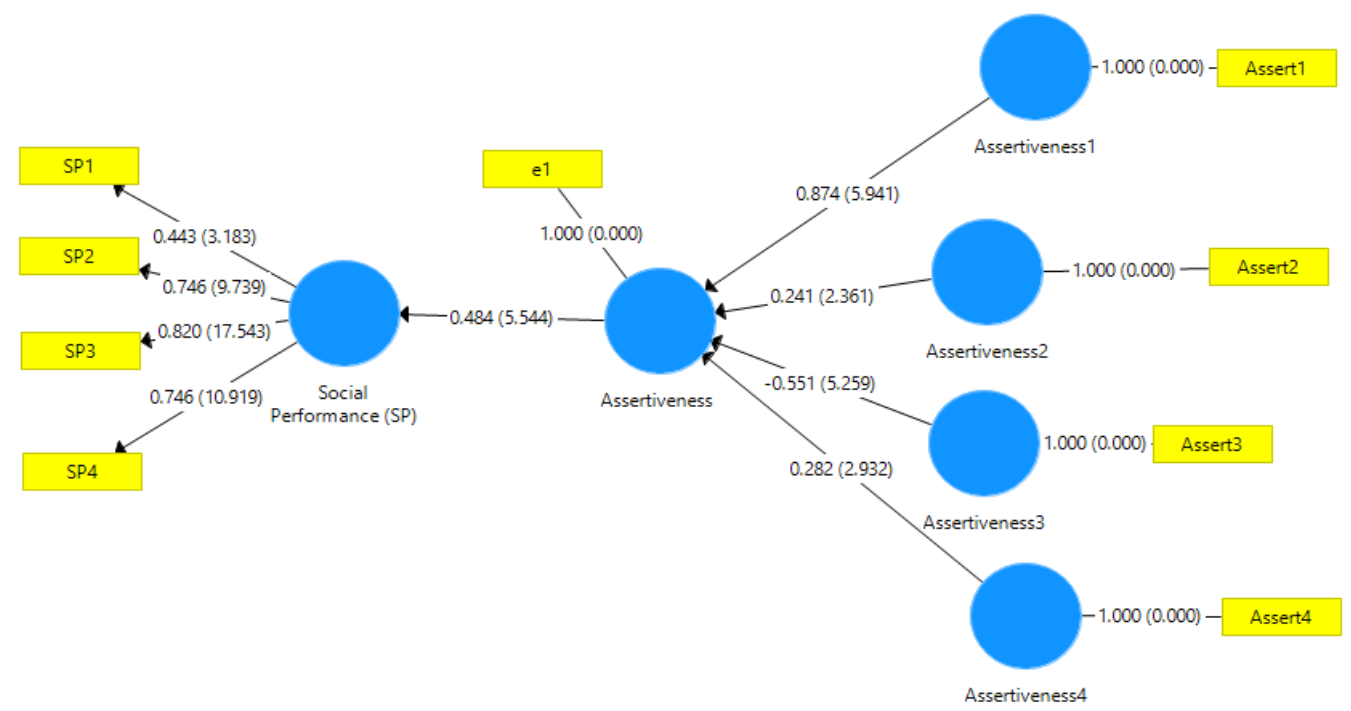

Figure 3: PLS Bootstrapping Model with $\beta$ and T Values

PLS bootstrapping depicted in Figure 3 shows the standardised $\beta$ coefficient and smart PLS path coefficients. The $\beta$ value suggests the expected variance in the social performance for a unit variation in the 
assertiveness of women entrepreneurs, which was used to test the significance of hypothesis formulated. However, greater the $\beta$ value the greater the effect on assertiveness of women entrepreneurs. The significant effect of assertiveness of women entrepreneurs on social performance was confirmed through the $\mathrm{T}$-value. Meanwhile, the path co-efficient, $\mathrm{T}$ value, $\mathrm{P}$ value, indirect effect and standard deviation is presented in Table 2.

Table 2: Path Co-efficient for the Hypothesis

\begin{tabular}{|c|c|c|c|c|c|}
\hline Variables & Path Co-efficient & Indirect Effect & $\begin{array}{l}\text { Standard } \\
\text { Deviation }\end{array}$ & T Statistics & $\begin{array}{c}P \\
\text { Values }\end{array}$ \\
\hline Asset $\rightarrow$ SP & 0.484 & 0.497 & 0.087 & 5.544 & 0.000 \\
\hline Asset $1 \rightarrow$ Asset & 0874 & & 0.147 & 5.941 & 0.000 \\
\hline Asset $1 \rightarrow \mathrm{SP}$ & & 0.423 & 0.116 & 3.652 & 0.000 \\
\hline Asset $2 \rightarrow$ Asset & 0.241 & & 0.102 & 2.361 & 0.019 \\
\hline Asset $2 \rightarrow$ SP & & 0.117 & 0.056 & 2.099 & 0.036 \\
\hline Asset $3 \rightarrow$ Asset & -0.551 & & 0.105 & 5.259 & 0.000 \\
\hline Asset $3 \rightarrow$ SP & & -0.267 & 0.058 & 4.602 & 0.000 \\
\hline Asset $4 \rightarrow$ Asset & 0.282 & & 0.096 & 2.932 & 0.004 \\
\hline Asset $4 \rightarrow$ SP & & 0.137 & 0.045 & 3.087 & 0.002 \\
\hline \multicolumn{6}{|c|}{ R Square } \\
\hline & & \multicolumn{2}{|c|}{ R Square } & \multicolumn{2}{|c|}{ Adjusted R Square } \\
\hline \multicolumn{2}{|c|}{ Assertiveness (Asset) } & \multicolumn{2}{|c|}{0.830} & \multicolumn{2}{|c|}{0.823} \\
\hline \multicolumn{2}{|c|}{ Social Perfromance (SP) } & \multicolumn{2}{|l|}{0.235} & \multicolumn{2}{|c|}{0.227} \\
\hline
\end{tabular}

Table 2 depicts the PLS statistical results of the structural model for hypothesis three. It was revealed that the structural path co-efficient of the four measures of assertiveness of women entrepreneurs represented in table as Asset1 -Asset4 i.e. Asset1=Confident in the quality of products/services, Asset2=Focusing on task, Asset3=Solving problems immediately, Asset $4=$ Customers wants identification indicate significant relationship at 0.05 . In addition, the path co-efficient also revealed that confident in the quality of products/services (Asset1) indirectly and significantly influenced social performance $(\beta=0.423$, T-value= 3.652, P-value $=0.000<0.05$ ). Similarly, it was also discovered that focusing on task (Asset2) has indirect significant influence on social performance $(\beta=0.117, T$-value $=2.099$, $P$-value $=0.036<0.05)$. Meanwhile solving problems immediately (Asset3) also has a negative indirect significant influence on social responsibility $(\beta=-0.267, \mathrm{~T}$-value $=4.602$, $\mathrm{P}$-value $=0.000<0.05)$ while customers wants identification (Asset4) has indirect significant influence on market share $(\beta=0.137$, T-value $=3.087, P$-value $=0.002<0.05)$. Looking at the specific measurement of assertiveness of women entrepreneurs, it was discovered that confident in the quality of products/services has the highest beta value that best predict assertiveness of women entrepreneurs.

Generally, the path co-efficient shows that the level of influence of assertiveness of women entrepreneurs on social performance is statistically significant with beta value of 0.484 with T-Statistical value of 5.544 and pvalue of 0.000 . This implies that assertiveness of women entrepreneurs has significant influence on social performance. Largely, the beta value of 0.484 suggests $48.4 \%$ influence on principal variable i.e. if one unit of assertiveness of women entrepreneurs increases, then $48.4 \%$ social performance will increase. Meanwhile, the T-value of 5.544 shows the statistical significant influence of assertiveness of women entrepreneurs on social performance with $p$-value of 0.000 .

Table 3: Goodness of Fit Statistics

\begin{tabular}{|l|c|c|}
\hline Model fit Indicators & Benchmark & Saturated Model Output \\
\hline SRMR & $<0.08$ & 0.075 \\
\hline CMIN/DF & $<3$ & 0.322 \\
\hline d-G (Geodesic Distance) & $>0.08$ & 0.223 \\
\hline Chi Square & $>0.05$ & 108.58 \\
\hline
\end{tabular}




\begin{tabular}{|l|r|r|}
\hline NFI & Between 0 + 1 & 0.872 \\
\hline
\end{tabular}

SRMR $=$ Standardized Root Mean Square Residual

d_G= Geodesic Distance

$\mathrm{NFI}=$ Normed Fit Index

Table 3 reveals various forms of Goodness-of-fit indicators threshold in assessing specified model of the study. The goodness of fit indices presented in the table are within the benchmark range of acceptance as recommend by Klarner, Sarstedt, Hoeck, and Ringle (2013) and Hair, Sarstedt, Ringle, and Mena (2012). The SRMR value is 0.075 , which is less than the acceptable benchmark value of 0.08 and NFI value is 0.872 within the $0+1$ suggest a good fit of the model. In addition, chi-square per degree of freedom ratio ( $\left.x^{2} / \mathrm{df}\right)$ and other indicators presented in table are within the threshold.

\section{FINDINGS AND DISCUSSION}

The findings of the analysis of the hypothesis shows assertiveness of women entrepreneurs have a significant effect on social performance of SMEs. This implies that all the items of measure for assertiveness (confidence on quality, focusing on tasks and identifying customer's want) have a positive and significant relationship with social performance. However, one of the items of measurement for assertiveness have a negative relationship with the social performance. This implies that trying to solve problems immediately they occur while trying to minimize future occurrence has a negative implication on social performance. Customers' wants identification and the entrepreneurs' confidence in the quality of their product and services have the highest significant impact on improving social performance of the SME. A major twist was the discovery that women entrepreneurs do not assign funds for social performance, which is in line with the research by López-Valladares and Díaz-Gamarra (2019) who argued that social performance is commonly perceived to be a high strategic value task for businesses. However, in the case of micro-enterprises, it was believed that it was not a priority because of the lack of capital and the need to survive at first. The empirical study of Chukwuemeka (2019), noted, however, that the social performance of women entrepreneurs is an creative bottom-down incentive that seeks to help the society develop economically in a sustainable manner and to deliver it effectively. This opinion was reinforced by Northouse (2016), who argued that women are becoming more assertive and masculine in their approach to leadership without compromising their feminine nature, which makes them better off in business and, as they are more assertive, continue to become conscious of their responsibility to their business setting.

\section{CONCLUSION AND RECOMMENDATIONS}

There is also a clear evidence that most women entrepreneurs do not allocate fund for social performance rather they depend on the confidence they have about the goods and services that they offer. This is a clear indication that offering social responsibilities is not part of their plan and this needs to be corrected as it may lead to a better business performance if adopted, as it will increase the trust from the customers. The study concludes that the women entrepreneurs do not have a supportive environment to create new things and ideas, although this has also motivated them to discover new ways of looking at problems to ensure the survival of the business. The Nigerian government is encouraged to provide creative enabling environment for business owners in the country. The study therefore recommends that because social performance is an integral part of business, all women entrepreneurs are encouraged to participate actively. This will create an enabling environment and will increase customer satisfaction. The entrepreneur can engage in activities like encouraging recycling, sponsoring a fundraiser for an important community project. They can offer academic scholarship or get involved in community service and most importantly get involved in promoting a responsible behavior in the community where their business is located. The entrepreneur should create a social performance strategy and engage in social responsibility communication to their customers. Government should also provide an enabling and encouraging environment to ensure that entrepreneurs are motivated to engage in social performance.

\section{ACKNOWLEDGEMENT}

The authors of this paper kindly appreciates Covenant University for taking full sponsorship for the payment of this paper. 


\section{REFERENCE LIST}

Abdullahi, M. S., Abubakar, A., Aliyu, R. L., Umar, K., Umar, M. B., Sabiu, I. T., ... \& Abubakar, L. S. (2015). The nature of Small and Medium Scale Enterprises (SMEs): Government and financial institutions support in Nigeria. International Journal of Academic Research in Business and Social Sciences, 5(3), 525-537.

Anlesinya, A., Adepoju, O. A., \& Richter, U. H. (2019). Cultural orientation, perceived support and participation of female students in formal entrepreneurship in the sub-Saharan economy of Ghana. International Journal of Gender and Entrepreneurship, 11 (3), 299-322.

Bikefe, G., Zubairu, U., Araga, S., Maitala, F., Ediuku, E., \& Anyebe, D. (2020). Corporate Social Responsibility (CSR) by small and medium enterprises (SMEs): a systematic review.

Eib, C. \& Siegert, S. (2019). Is female entrepreneurship only empowering for single women? Evidence from France and Germany. Journal of Social Sciences. 8, 128.

Henseler, J. \& Ringle, C. \& Sinkovics, R. (2009). The Use of Partial Least Squares Path Modeling in International Marketing. 10.1108/S1474-7979(2009)0000020014.

López-Valladares, H., Díaz-Gamarra, M., \& Mendoza, J. (2019, September). Corporate Social Responsibility Effects in Micro Entrepreneurship Ventures Run by Women. In International Conference on Innovation and Entrepreneurship (pp. 612-XVII). Academic Conferences International Limited.

Moses, C., Olokundun, A. M., Akinbode, M., \& Agboola, M. G. (2016). Organizational culture and creativity in entrepreneurship education: a study of secondary education in Nigeria. Research Journal of Applied Sciences, 11(8), 586-591.

Northouse, P. 2016. Leadership: Theory and practice. Thousand Oaks, CA: Sage Publications, Inc.

Nwosu, M. (2019). Youth entrepreneurship among university graduates in Anambra, Nigeria (Doctoral dissertation, Walden University).

Ojinta, R. I., \& Halkias, D. (2019). Nigerian Women Entrepreneurial Leaders: A Narrative Literature Review. Available at SSRN 3449158.

Udemba, N. F. (2020). Skills needed for successful management of small and medium scale manufacturing industries by entrepreneurs in Anambra State, Nigeria. European Journal of Education Studies.

Wong, K. (2013). Partial least square structural equation modeling (PLS-SEM) techniques using SmartPLS. Marketing Bulletin. 24. 1-32. 